\title{
Improvement of Steering Feel of Electric Power Steering System with Variable Gear Transmission System Using Decoupling Control
}

\author{
Yoshifumi Morita Senior Member (Nagoya Institute of Technology, morita@nitech.ac.jp) \\ Akitoshi Yokoi Student Member (Nagoya Institute of Technology) \\ Makoto Iwasaki Senior Member (Nagoya Institute of Technology) \\ Hiroyuki Ukai Senior Member (Nagoya Institute of Technology) \\ Nobuyuki Matsui Senior Member (Nagoya Institute of Technology) \\ Norihisa Ito Non-member (DENSO Corporation) \\ Nobuhiko Uryu Non-member (DENSO Corporation) \\ Yasuhiko Mukai Non-member (DENSO Corporation)
}

Keywords: electric power steering, variable gear transmission system, decoupling control, steering feel, Lissajous curve

Recently the electric power steering (EPS) system has been widely used in automobile. It enables us to reduce manufacturing cost and to improve fuel efficiency as compared with the traditional hydraulic power steering system. Moreover, recently the variable gear transmission system (VGTS) has received a great deal of attention. It enables us to vary the amount of tire movement by changing the steering gear ratio according to road speed. Thus the VGTS increases maneuverability. High class automobiles are equipped with the EPS system with the VGTS (EPS-VGTS system). However, it is difficult to tune controller gains so as to increase maneuverability, because the EPS-VGTS system has two inputs and these two control systems are coupled with each other. Moreover, since the moment of inertia of the steering increases due to the two motors, namely the EPS and VGTS motors, the degradation of maneuverability has to be improved. In this system these two issues on controller design have to be considered.

In this paper a new control method is proposed for the EPS system with the VGTS as shown in Fig. 1. The proposed control system is designed by applying decoupling control theory to the EPS-VGTS system and using two servo controllers. In this method we can separately consider gear ratio control and power assist control with good steering feel at controller design phase. The decoupled systems are torque control system and angle control system. In angle control system the PID control is used to achieve the desired gear ratio. In torque control system the PID control is used to achieve the desired torque designed so as to achieve good steering feel and power assist. The desired torque is calculated on the basis of the ideal model. In order to evaluate steering feel the Lissajous curve between the steering torque and the steering angle is used. The requirement for good steering feel is defined as follows; in the Lissajous curve in the range of the steering frequency band $0.2-1.8[\mathrm{~Hz}]$, (i) the phase lag between the steering angle and torque is reduced and (ii) the oscillation is suppressed. The effectiveness of the proposed control system

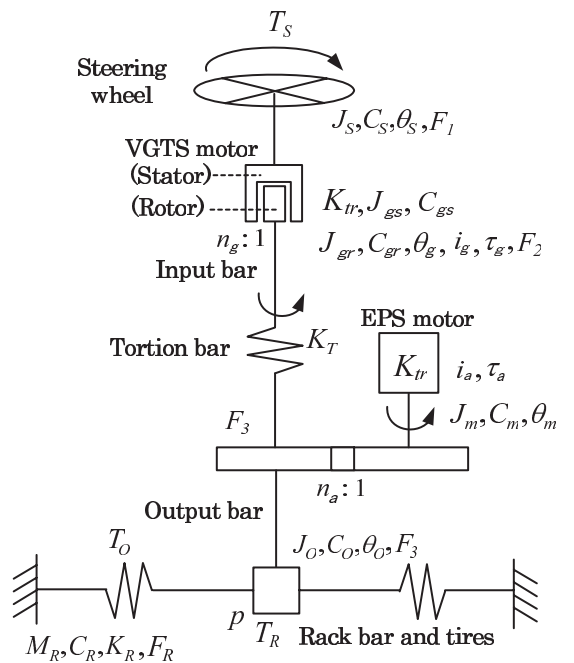

Fig. 1. EPS-VGTS model
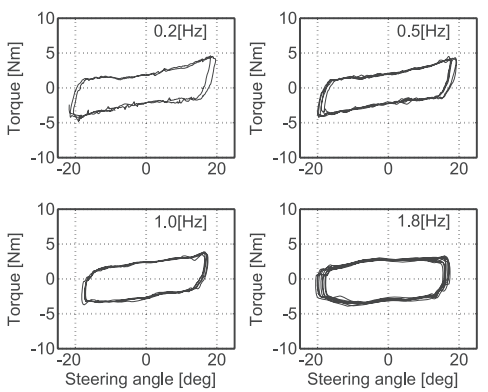

Fig. 2. Lissajous curves with proposed controller (Gear ratio $z=1$ )

is verified using a test bench. The Lissajous curves with the proposed controller is shown in Fig. 2. It is seen from Fig. 2 that the steering feel can be improved. Moreover, it is found that the gear ratio control and the power assist control can be achieved by using the proposed controller. 


\section{非干渉制御を用いた可変ギア伝達機構付 電動パワーステアリングの操作感性向上}

$\begin{array}{cccccc}\text { 上級会員 } & \text { 森田 } & \text { 良文* } & \text { 学生員 } & \text { 横井 } & \text { 彰敏* } \\ \text { 上級会員 } & \text { 岩崎 } & \text { 誠* }^{*} \text { 上級会員 } & \text { 鵜飼 } & \text { 裕之* } \\ \text { 上級会員 } & \text { 松井 } & \text { 信行* } & \text { 非会員 } & \text { 伊藤 } & \text { 徳久** } \\ \text { 非会員 } & \text { 瓜生 } & \text { 信彦** } & \text { 非会員 } & \text { 向井 } & \text { 靖彦** }\end{array}$

Improvement of Steering Feel of Electric Power Steering System with

Variable Gear Transmission System Using Decoupling Control

Yoshifumi Morita*, Senior Member, Akitoshi Yokoi*, Student Member, Makoto Iwasaki*, Senior Member, Hiroyuki Ukai*, Senior Member, Nobuyuki Matsui*, Senior Member, Norihisa Ito**, Non-member, Nobuhiko Uryu**, Non-member, Yasuhiko Mukai**, Non-member

In this paper a new control method of Electric Power Steering (EPS) system with Variable Gear Transmission System (VGTS) is proposed. The control purpose is to achieve the desired steering gear ratio and the desired power assist with good steering feel. The basic idea of controller design is to apply decoupling control to this system and to separately design controllers for two decoupled systems. The angle control system and the torque control system are designed for the decoupled systems. In the angle control system the PID control is used for the desired gear ratio. In the torque control system the PID control is used for the desired assist torque designed so as to achieve good steering feel. In order to evaluate steering feel the Lissajous curve between the steering torque and steering angle is used. The effectiveness of the proposed controller is verified experimentally.

キーワード：電動パワーステアリング, 可変ギア伝達機構, 非干渉制御, 操作感性, リサージュ波形

Keywords: electric power steering, variable gear transmission system, decoupling control, steering feel, Lissajous curve

\section{1. はじめに}

現在，多くの自動車にパワーステアリングシステムが装 備され, ドライバは軽い力で操舵することが可能となってき た。さらに最近では, 電動モータによりアシストトルクを生 成する電動式パワーステアリング（Electric Power Steering 以下，EPS と呼ぶ）が，油圧ポンプによりアシストト ルクを生成する油圧式パワーステアリングに代わって主流 となりつつある(1)。このような広がりを支える技術として， EPS による操舵トルクの低滅 ${ }^{(2)}$, EPS による路面反力の

\footnotetext{
* 名古屋工業大学

于 466-8555 名古屋市昭和区御器所町

Nagoya Institute of Technology

Gokiso-cho, Showa-ku, Nagoya, Aichi 466-8555

** (株) デンソー

干 448-8661 愛知県刈谷市昭和町 1-1

DENSO Corporation

1-1 Showa-cho, Kariya, Aichi 448-8661
}

伝達 ${ }^{(3)}$, 車両の安定化 ${ }^{(4)}$ など, 種々の研究 ${ }^{(5)}$ ( (9) がなされ てきた。

さらに，現在のステア制御の技術動向として，より快適性 を高めるために走行支援領域の拡大や, 安全性を高めるた めにドライバの意思サポート領域の拡大を目的とした, 舵 角制御の技術が取り入れられはじめている ${ }^{(10)}$ 。その中の代 表的なシステムとして, 電動モー夕を用いた可変ギア伝達 機構（Variable Gear Transmission System 以下, VGTS と呼ぶ）がある。これは, 速度に応じて, ステアリングの操 作量に対する夕イヤの切れ角であるステアリングギア比を フレキシブルに変化させるシステムである。低速時にはス テアリングギア比を大きくして車庫入を容易にし, 高速時 には逆に小さくして高速道のレーンチェンジでの安定度を 高める。また, エンジンやブレーキといった他の機構と連 動して働くことにより, 車両の挙動を安定に保ち, 高い予 防安全性や理想的な車両運動性能を実現することができる。 しかしながら, EPS とVGTS を統合したステアリング 
システム（以下 EPS-VGTS と呼ぶ）では，二つのモータ 間で相互干渉が発生するためコントローラのゲインチュー ニングが困難になるといった問題がある。さらに，本研究 で扱うコラム式の VGTS の場合，ステアリングシャフトに VGTS モータが取り付けられるためステアリングホイール 周りの慣性モーメントが増加し，これにより操作感性が劣 化するといった問題もある。

本研究では，コラム式の VGTS-EPS に対して非干渉制 御を導入し, 非干渉化された角度制御系においてはギア比 制御を, トルク制御系においては操作感性の良いパワーア シスト制御を実現するコントローラ設計法を提案する。こ のようなモデルベース開発によるシステマティックなコント ローラ設計法を提案することで，コントローラのチューニ ングが容易になるばかりか，システムの設計変更にも柔軟 に対応できることが期待される。最後に，テストベンチにお いて検証実験を行い,リサージュ波形を用いた評価 ${ }^{(11)(12)}$ によって操作感性の向上を確認する。

\section{EPS-VGTS のモデル}

本研究で扱うコラム式の EPS-VGTS のモデルを Fig. 1 に示す。ここで用いる物理定数と变数を Table 1 に示す。ス テアリングホイール（以降ステアリングと呼ぶ）はVGTS モータのステータに固定され, VGTS モータのロータと入 力軸が固定されている。これにより，ステアリングを $\theta_{s}$ た け回転させると，それに併せてVGTS モータのステータも $\theta_{s}$ だけ回転し，さらにVGTS モータのロータを $\theta_{g}$ だけ回 転させると, 入力軸の回転角度 $\theta_{s g}$ は,

$$
\theta_{s g}=\theta_{s}+\theta_{g}
$$

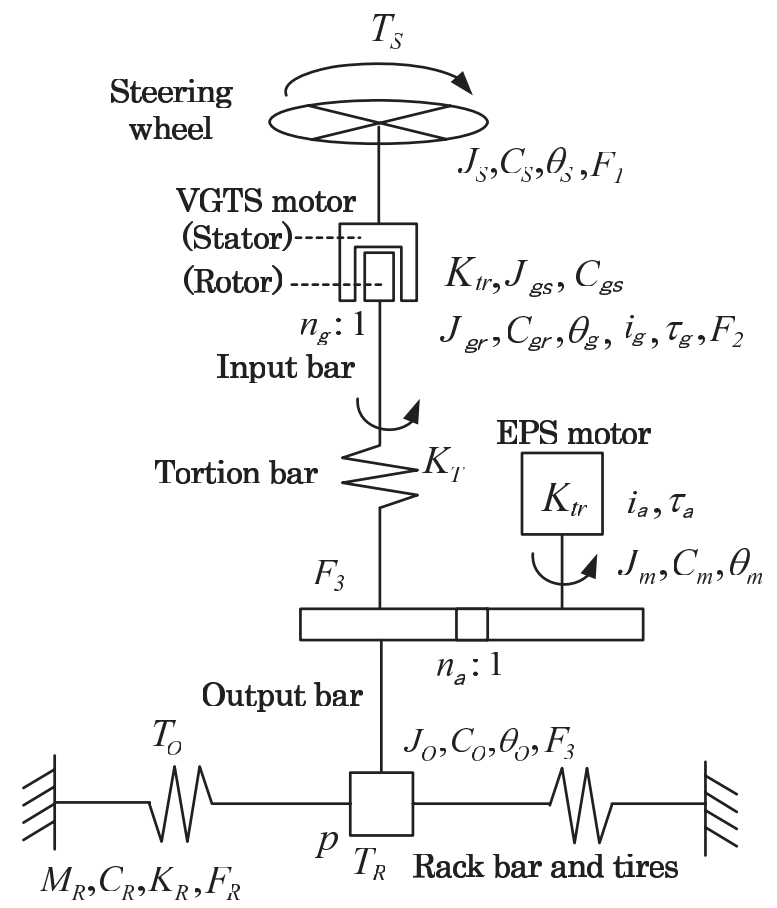

Fig. 1. EPS-VGTS model
となる。ギア比 $z$ は, 出力軸の回転角度を $\theta_{0}$ とすると,

$$
z=\frac{\theta_{o}}{\theta_{s}}
$$

として表される。また，ドライバのステアリングトルクを $T_{s}$, VGTS モータのトルクを $\tau_{g}$, EPS モータのトルクを $\tau_{a}$ とする。

この EPS-VGTS の運動方程式を導出すると以下となる。 ステアリングならびに VGTS モータのステータに関する 運動方程式：

Table 1. Notation of physical parameters and vari-

\begin{tabular}{|c|c|}
\hline Parameters & \\
\hline Moment of inertia of steering wheel & $J_{s}\left[\mathrm{~kg} \cdot \mathrm{m}^{2}\right]$ \\
\hline Moment of inertia of stator of VGTS motor & $J_{g s}\left[\mathrm{~kg} \cdot \mathrm{m}^{2}\right]$ \\
\hline $\begin{array}{l}\text { Moment of inertia of rotor } \\
\text { of VGTS motor with gear }\end{array}$ & $J_{g r}\left[\mathrm{~kg} \cdot \mathrm{m}^{2}\right]$ \\
\hline Moment of inertia of output bar & $J_{o}\left[\mathrm{~kg} \cdot \mathrm{m}^{2}\right]$ \\
\hline Moment of inertia of EPS motor & $J_{m}\left[\mathrm{~kg} \cdot \mathrm{m}^{2}\right]$ \\
\hline Mass of rack & $M_{R}[\mathrm{~kg}]$ \\
\hline Damping coefficient of steering wheel & $C_{s}\left[\mathrm{~kg} \cdot \mathrm{m}^{2} / \mathrm{s}\right]$ \\
\hline Damping coefficient of stator of VGTS motor & $C_{g s}\left[\mathrm{~kg} \cdot \mathrm{m}^{2} / \mathrm{s}\right]$ \\
\hline $\begin{array}{l}\text { Damping coefficient of rotor } \\
\text { of VGTS motor with gear }\end{array}$ & $C_{g r}\left[\mathrm{~kg} \cdot \mathrm{m}^{2} / \mathrm{s}\right]$ \\
\hline Damping coefficient of output bar & $C_{o}\left[\mathrm{~kg} \cdot \mathrm{m}^{2} / \mathrm{s}\right]$ \\
\hline Damping coefficient of EPS motor & $C_{m}\left[\mathrm{~kg} \cdot \mathrm{m}^{2} / \mathrm{s}\right]$ \\
\hline Damping coefficient of rack & $C_{R}[\mathrm{~kg} / \mathrm{s}]$ \\
\hline Spring constant of input bar & $K_{T}[\mathrm{~N} \cdot \mathrm{m}]$ \\
\hline Spring constant of rack & $K_{R}[\mathrm{~N} / \mathrm{m}]$ \\
\hline Gear ratio of VGTS motor & $n_{g}$ \\
\hline Gear ratio of EPS motor & $n_{a}$ \\
\hline Stroke ratio & $p[\mathrm{~m} / \mathrm{rev}]$ \\
\hline Coulomb friction torque of steering wheel & $F_{s}[\mathrm{~N} \cdot \mathrm{m}]$ \\
\hline $\begin{array}{c}\text { Coulomb friction torque of stator } \\
\text { of VGTS motor }\end{array}$ & $F_{g s}[\mathrm{~N} \cdot \mathrm{m}]$ \\
\hline $\begin{array}{l}\text { Coulomb friction torque of rotor } \\
\text { of VGTS motor with gear }\end{array}$ & $F_{g r}[\mathrm{~N} \cdot \mathrm{m}]$ \\
\hline Coulomb friction torque of output bar & $F_{o}[\mathrm{~N} \cdot \mathrm{m}]$ \\
\hline Angle of steering wheel & $\theta_{s}[\mathrm{rad}]$ \\
\hline Angle of VGTS motor with gear & $\theta_{g}[\mathrm{rad}]$ \\
\hline Angle of input bar & $\theta_{s g}[\mathrm{rad}]$ \\
\hline Angle of output bar & $\theta_{o}[\mathrm{rad}]$ \\
\hline Angle of EPS motor & $\theta_{m}[\mathrm{rad}]$ \\
\hline Steering torque & $T_{s}[\mathrm{~N} \cdot \mathrm{m}]$ \\
\hline Torsion torque & $T_{s n}[\mathrm{~N} \cdot \mathrm{m}]$ \\
\hline Torque of VGTS motor & $\tau_{g}[\mathrm{~N} \cdot \mathrm{m}]$ \\
\hline Torque of EPS motor & $\tau_{a}[\mathrm{~N} \cdot \mathrm{m}]$ \\
\hline Torque of EPS motor with gear & $T_{m}[\mathrm{~N} \cdot \mathrm{m}]$ \\
\hline Torque acting on pinion shaft & $T_{R}[\mathrm{~N} \cdot \mathrm{m}]$ \\
\hline Force acting on rack & $F_{R}[\mathrm{~N}]$ \\
\hline
\end{tabular}
ables

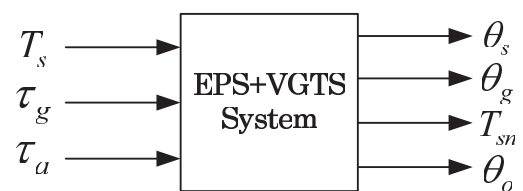

Fig. 2. EPS-VGTS system 


$$
T_{s}-\tau_{g}=\left(J_{s}+J_{g s}\right) \frac{d^{2} \theta_{s}}{d t^{2}}+\left(C_{s}+C_{g s}\right) \frac{d \theta_{s}}{d t}+F_{s v}
$$

VGTS モータのロータに関する運動方程式 :

$$
\tau_{g}-T_{s n}=J_{g r} \frac{d^{2} \theta_{s g}}{d t^{2}}+C_{g r} \frac{d \theta_{s g}}{d t}+F_{g r}
$$

出力軸周りの運動方程式 :

$$
T_{s n}+T_{m}-T_{R}=J_{o} \frac{d^{2} \theta_{o}}{d t^{2}}+C_{o} \frac{d \theta_{o}}{d t}+F_{o}
$$

ラックに関する運動方程式：

$$
F_{R}=M_{R} \frac{d^{2} x_{R}}{d t^{2}}+C_{R} \frac{d x_{R}}{d t}+K_{R} x_{R}
$$

EPS モー夕に関する運動方程式 :

$$
T_{m}=n_{a}\left(K_{t r}^{a} i_{a}-J_{m} \frac{d^{2} \theta_{m}}{d t^{2}}-C_{m} \frac{d \theta_{m}}{d t}\right) \cdots
$$

ここで, $x_{R}=p \theta_{o} /(2 \pi), \quad T_{R}=p F_{R} /(2 \pi), \quad \theta_{m}=n_{a} \theta_{o}$ $F_{s v}=F_{s}+F_{g s}+F_{g r}$ とする。 $F_{s}, F_{g s}, \quad F_{g r}, \quad F_{o}$ はクー ロン摩擦トルクを表す。ラックのバネはタイヤからの路面 反力を想定したものである。また，トーションバーにはト ルクセンサが取り付けられており，そのねじれトルクの值 を $T_{s n}$ とすると, 次式で表される。

$$
T_{s n}=K_{T}\left(\theta_{s}+\theta_{g}-\theta_{o}\right)
$$

(5), (6), (7) 式は一つにまとめることができ, これと (3), (4) 式をあわせることで, EPS-VGTS は 3 慣性系の集中定 数システムとみなすことができる。また，このEPS-VGTS の入出力関係は Fig. 2 に示す通りで, $T_{s}, \tau_{g}, \tau_{a}$ が入力, $\theta_{s}, \theta_{g}, T_{s n}, \theta_{o}$ がセンサ出力のシステムとなる。

\section{3. リサージュ波形による操作感性の評価}

ドライバによるステアリング操舵の操作感性を定量的に 評価するために，リサージュ波形を用いる(11)(12)。これは， ドライバがステアリングを正弦波状に左右に操舵した際の ステアリング角度 $\theta_{s}$ とステアリングトルク $T_{s}$ をそれぞれ 横軸と縦軸にプロットしたものである。ただし，正弦波の 振幅と周波数は一定とする。

本研究では, ドライバの操舵周波数帯域から判断して, 振幅を $20[\mathrm{deg}]$ 一定とし, 一定の周波数として $0.2[\mathrm{~Hz}]$, $0.5[\mathrm{~Hz}], \quad 1.0[\mathrm{~Hz}], 1.8[\mathrm{~Hz}]$ の 4 通りについて操作感性を調 ベる。また, VGTS と EPS の二つのモータの慣性と粘性 の影響に起因する操作感性の劣化改善策を考えるため，二 つのモータの慣性や粘性の影響がない状態のリサージュ波 形を操作感性の良いものとして定義し，これを理想状態と 呼ぶ。この求め方は $\langle 4 \cdot 3 \cdot 2\rangle$ 節に示す。

\section{4. 非干渉制御に基づく制御系設計}

EPS-VGTSにおける制御目的は，ギア比制御を行うこ とと同時に，モータの慣性や粘性に起因する操作感性の劣
化を改善しつつパワーアシスト制御を実現することにある。 このために, VGTS モータの指令トルクと EPS モータの 指令卜ルクの両方を設計することになる。しかしながら, EPS と VGTS の二つの制御系が互いに干渉するため，こ れらのコントローラのゲインチューニングが困難となる。 そこで，非干渉制御を適用することで，二つの制御系にお いてコントローラを個別設計する手法を提案する。これに より，二つの制御目的に対するコントローラの設計の指針 が立てやすくなり，コントローラのゲインチューニングが 容易になるばかりか, 性能の向上も期待される。

$\langle\mathbf{4} \cdot \mathbf{1}\rangle$ 状態空間モデル (1) - (8) 式で表されたEPSVGTS の運動方程式をまとめると次式で表される。

$$
\hat{J} \ddot{\theta}+\hat{C} \dot{\theta}+\hat{K} \theta=\hat{T} u
$$

ただし，制御系設計を考える上で，ドライバのステアリン グトルク $T_{s}$ と, 非線形項であるクーロン摩擦トルクを無 視する。ここで,

$$
\begin{aligned}
& \theta=\left[\begin{array}{lll}
\theta_{s} & \theta_{g} & \theta_{o}
\end{array}\right]^{T}, \quad u=\left[\begin{array}{ll}
\tau_{g} & \tau_{a}
\end{array}\right]^{T}, \\
& \hat{J}=\left[\begin{array}{ccc}
J_{1} & J_{g r} & 0 \\
J_{g r} & J_{g r} & 0 \\
0 & 0 & J_{2}
\end{array}\right], \quad \hat{C}=\left[\begin{array}{ccc}
C_{1} & C_{g r} & 0 \\
G_{g r} & C_{g r} & 0 \\
0 & 0 & C_{2}
\end{array}\right], \\
& \hat{K}=\left[\begin{array}{ccc}
K_{T} & K_{T} & -K_{T} \\
K_{T} & K_{T} & -K_{T} \\
-K_{T} & -K_{T} & K_{2}
\end{array}\right], \quad \hat{T}=\left[\begin{array}{ll}
0 & 0 \\
1 & 0 \\
0 & 1
\end{array}\right], \\
& J_{1}=J_{s}+J_{g s}+J_{g r}, \quad C_{1}=C_{s}+C_{g s}+C_{g r}, \\
& J_{2}=J_{o}+n_{a}^{2} J_{m}+(p / 2 \pi)^{2} M_{R}, \\
& C_{2}=C_{o}+n_{a}^{2} C_{m}+(p / 2 \pi)^{2} C_{R}, \\
& K_{2}=K_{T}+(p / 2 \pi)^{2} K_{R}
\end{aligned}
$$

である。いま， 状態変数を $x=\left[\begin{array}{ll}\theta^{T} & \dot{\theta}^{T}\end{array}\right]^{T}$ とおくと，(9) 式は，以下の状態空間モデルで表される。

$$
\begin{aligned}
& \left\{\begin{array}{l}
\dot{x}=A x+B u \\
y=C x
\end{array}\right. \\
& A=\left[\begin{array}{cc}
0 & I \\
-\hat{J}^{-1} \hat{K} & -\hat{J}^{-1} \hat{C}
\end{array}\right], \quad B=\left[\begin{array}{c}
0 \\
\hat{J}^{-1} \hat{T}
\end{array}\right], \\
& C=\left[\begin{array}{l}
c_{1} \\
c_{2}
\end{array}\right]=\left[\begin{array}{cccccc}
0 & 1 & 0 & 0 & 0 & 0 \\
K_{T} & K_{T} & -K_{T} & 0 & 0 & 0
\end{array}\right],
\end{aligned}
$$

ここでは， 4.2 節以降で述べる制御系設計のために，制御 量 $y$ をVGTS モータの回転子角度 $\theta_{g}$ とトルクセンサの值 $T_{s n}$ の二つとする。

〈4・2〉 非干渉制御ＥPS-VGTS に非干渉制御理論を 適用する。ここでは, 以下の状態フィードバック制御則を 用いる。

$$
u=F x+G v
$$

ここで $v=\left[\begin{array}{ll}v_{1} & v_{2}\end{array}\right]^{T}$ は新たな制御入力であり, フィード バックゲイン $F$ と $G$ は次式で表される。 


$$
\begin{aligned}
F= & -B^{*-1} C^{*} \ldots \ldots \ldots \ldots \ldots \ldots \ldots \ldots \ldots \\
G= & B^{*-1} \ldots \ldots \ldots \ldots \ldots \ldots \ldots \ldots \ldots \\
B^{*}= & {\left[\begin{array}{l}
c_{1}^{T} A B \\
c_{2}^{T} A B
\end{array}\right]=\left[\begin{array}{cc}
\frac{J_{1}}{J_{g r}\left(J_{s}+J_{g s}\right)} & 0 \\
\frac{K_{T}}{J_{g r}} & \frac{-K_{T}}{J_{2}}
\end{array}\right], } \\
C^{*}= & {\left[\begin{array}{l}
c_{1}^{T} A^{2} \\
c_{2}^{T} A^{2}
\end{array}\right] } \\
= & {\left[\begin{array}{cc}
\frac{-K_{T}}{J_{g r}} & \frac{-K_{T}}{J_{g r}} \\
\frac{-K_{T}^{2}\left(J_{2}+J_{g r}\right)}{J_{2} J_{g r}} & \frac{-K_{T}^{2}\left(J_{2}+J_{g r}\right)}{J_{2} J_{g r}} \\
\frac{K_{T}}{J_{g r}} & \frac{J_{g r} C_{1}-J_{1} C_{g r}}{J_{g r}\left(J_{1}-J_{g r}\right)} \\
& \frac{K_{T}\left(K_{T} J_{2}+K_{2} J_{g r}\right)}{J_{2} J_{g r}} \\
& \frac{-C_{g r}}{J_{g r}} \\
& \frac{-K_{T} C_{g r}}{J_{g r}} \quad \frac{K_{T} C_{2}}{J_{2}}
\end{array}\right] \quad }
\end{aligned}
$$

非干渉化できるための必要十分条件は， $B^{*}$ が正則になるこ とである。このことは上述の $B^{*}$ の要素から明らかである。 非干渉化後の状態空間モデルと伝達関数は次式で表され, そのブロック図をFig. 3 に示す。

$$
\begin{aligned}
& \left\{\begin{array}{l}
\dot{x}=(A+B F) x+B G v \\
y=C x
\end{array}\right. \\
& H_{F G}(s)=C(s I-A-B F)^{-1} B G=\left[\begin{array}{cc}
\frac{1}{s^{2}} & 0 \\
0 & \frac{1}{s^{2}}
\end{array}\right]
\end{aligned}
$$

非干渉化されたシステムは，それぞれが 2 個の積分器を持 つ特性になる。これにより， $v_{1}$ から $\theta_{g}$ までの角度制御系 と, $v_{2}$ から $T_{s n}$ までのトルク制御系が非干渉化され，独立 して制御系設計が可能となる。

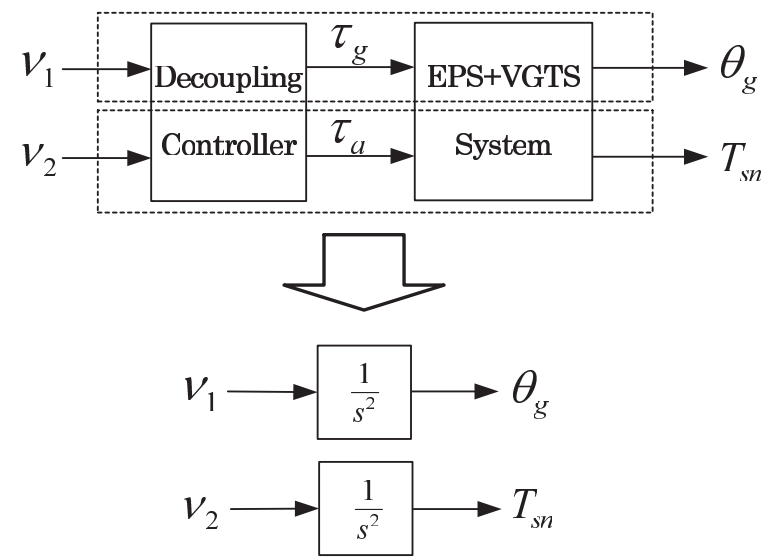

Fig. 3. Decoupled systems

\section{$\langle 4 \cdot 3\rangle$ 各制御系の設計}

$\langle\mathbf{4} \cdot \mathbf{3} \cdot \mathbf{1}\rangle$ 角度制御系の設計 角度制御系では, $v_{1}$ を 操作量に, VGTS モー夕の回転子角度 $\theta_{g}$ を制御量とする システムに対して，ギア比制御を実現する制御系を設計す る。目標のギア比を $z$ とすると, VGTS モー夕の回転子角 度 $\theta_{g}$ に対する目標值 $\theta_{g}^{r e f}$ は,

$$
\theta_{g}^{r e f}=(z-1) \theta_{s}
$$

となる。いま，目標のギア比を $0.5 ， 1 ， 2$ にすると，それ ぞれVGTS モー夕の目標回転角度は- $0.5 \theta_{s}, 0, \theta_{s}$ となる。 すなわち，ギア比を 1 とするとVGTS モータはロックされ た状態になり，ギア比が 1 を超えるとステアリングの回転 方向に対して VGTS モー夕は正回転をし, ギア比が1より 小さいときはステアリングの回転方向に対してVGTS モー 夕が逆回転をする。この目標值 $\theta_{g}^{r e f} に$ に追従するサーボ系と してPID コントローラを用いると, その制御入力 $v_{1}$ は,

$$
\begin{aligned}
v_{1}= & K_{P}^{g}\left(\theta_{g}^{r e f}-\theta_{g}\right)+K_{I}^{g} \int_{0}^{t}\left(\theta_{g}^{r e f}-\theta_{g}\right) d t \\
& +K_{D}^{g} \frac{d}{d t}\left(\theta_{g}^{r e f}-\theta_{g}\right) \cdots \cdots \cdots \cdots \cdots \cdots
\end{aligned}
$$

として表される。

$\langle\mathbf{4} \cdot \mathbf{3} \cdot \mathbf{2}\rangle$ トルク制御系の設計 トルク制御系では, $v_{2}$ を操作量, トルクセンサの值 $T_{s n}$ を制御量とするシステム に対して，操作感性の良い，パワーアシストを実現する制 御系を設計する。

まず，VGTS モータのギア比制御が達成されているもの とすると $\theta_{g}=\theta_{g}^{r e f}$ となり，これと (1), (3), (4), (16) 式 を用いると, ステアリングに関する運動方程式は

$$
\begin{aligned}
T_{s}= & \left(J_{s}+J_{g s}+z J_{g r}\right) \frac{d^{2} \theta_{s}}{d t^{2}} \\
& +\left(C_{s}+C_{g s}+z C_{g r}\right) \frac{d \theta_{s}}{d t}+T_{s n}
\end{aligned}
$$

となり, これをラプラス変換すると，

$$
\begin{aligned}
T_{s}(s)= & \left(J_{s}+J_{g s}+z J_{g r}\right) s^{2} \theta_{s}(s) \\
& +\left(C_{s}+C_{g s}+z C_{g r}\right) s \theta_{s}(s)+T_{s n}(s)
\end{aligned}
$$

となる。ただし,クーロン摩擦トルクを無視した。

さて, EPS-VGTS における操作感性を悪くする原因が, 二つのモータの慣性と粘性の影響にあるので, これらを無 視した理想モデルから, 理想状態のリサージュ波形を求め る。ここで, VGTS の慣性と粘性の影響を無視するために, VGTS モー夕を取り外して, ステアリングと入力軸が直結 されたシステムを考える。これにより，(3) 式と (4) 式から

$$
T_{s}^{\text {ideal }}=J_{s} \frac{d^{2} \theta_{s}}{d t^{2}}+C_{s} \frac{d \theta_{s}}{d t}+T_{s n}^{\text {ideal }}
$$

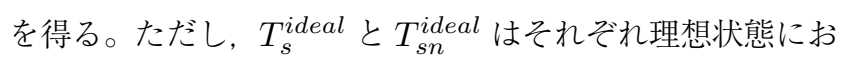
けるステアリングトルクとトルクセンサの值である。一方， EPS の慣性と粘性の影響を無視するために，(9) 式の行列 
表示の 3 行目の $J_{m}$ と $C_{m}$ を無視し, $\theta_{g}=0, \tau_{a}=0$ とす ると,

$$
T_{s n}^{i d e a l}=J_{3} \frac{d^{2} \theta_{o}}{d t^{2}}+C_{3} \frac{d \theta_{o}}{d t}+K_{3} \theta_{o} \cdots \cdots \cdots
$$

ただし $, J_{3}=J_{o}+(p / 2 \pi)^{2} M_{R}, C_{3}=C_{o}+(p / 2 \pi)^{2} C_{R}$, $K_{3}=(p / 2 \pi)^{2} K_{R}$,

$$
T_{\text {sn }}^{\text {ideal }}=K_{T}\left(\theta_{s}-\theta_{o}\right) \cdot
$$

とする。以上より，(20)，(21), (22) 式は理想のモデルを 表す。(20) 式は, Fig. 1 に扔けるトルクセンサより上部の 理想モデルを表すのに対し，(21) 式は，トルクセンサより 下部の理想モデルを表す。(20), (21)，(22) 式をラプラス 変換してまとめると,

$$
\begin{aligned}
& T_{s}^{\text {ideal }}(s)=\left\{\left(J_{s} s^{2}+C_{s} s\right)+G_{c}^{\text {ideal }}(s)\right\} \theta_{s}(s) \cdots \\
& G_{c}^{\text {ideal }}(s)=K_{T} \frac{J_{3} s^{2}+C_{3} s+K_{3}}{J_{3} s^{2}+C_{3} s+K_{3}+K_{T}}
\end{aligned}
$$

となり、これが理想状態のリサージュ波形となる。

さて，トルクセンサの目標值 $T_{s n}^{r e f}(s)$ は, (19) 式が (23) 式となるように決定すればよい。よって,

$$
\begin{aligned}
& T_{s n}^{r e f}(s)=\left\{G_{c}^{\text {cancel }}(s)+G_{c}^{\text {ideal }}(s)\right\} \theta_{s}(s) \cdots(24) \\
& G_{c}^{\text {cancel }}(s)=-\left\{\left(J_{g s}+z J_{g r}\right) s^{2}+\left(C_{g s}+z C_{g r}\right) s\right\}
\end{aligned}
$$

がトルクセンサの目標値となる。(24) 式の $G_{c}^{\text {cancel }}(s) \theta_{s}(s)$ の項によって, VGTS モータの慣性トルクや粘性トルクを キャンセルする項である。一方， $(24)$ 式の $G_{c}^{\text {ideal }}(s) \theta_{s}(s)$ の項は EPS モータの慣性トルクや粘性トルクの無い理想 状態を実現する目標トルクである。これらによって，良い 操作感性を実現する。

さらに，トルクセンサの值に応じて EPS モータがアシス トトルクを発生するといったパワーアシストを実現する必 要がある。ただし，トルクセンサの值が小さいときにはア シストトルクが発生しない不感帯が存在し，また車速度に 応じてアシストトルクの大きさが異なる。そこで，アシス トトルクをトルクセンサの值のゲイン倍 $K_{p a}$ と近似して, アシストトルクのためのトルクセンサの目標值 $T_{s n}^{r e f}(s)$ を 次式のように考える。

$$
\begin{aligned}
T_{s n}^{r e f}(s)= & \left\{K_{p a} G_{s}^{\text {cancel }}(s)+G_{c}^{\text {ideal }}(s)\right\} \theta_{s}(s) \\
& -K_{p a} T_{s n}(s) \ldots \ldots \ldots \ldots \ldots \ldots \ldots \ldots \ldots \ldots
\end{aligned}
$$

これより, トルクセンサの值 $T_{s n}(s)$ が大きくなると, トル クセンサの目標值 $T_{s n}^{r e f}(s)$ が小さな值となる。これにより, ステアリングトルク $T_{s}(s)$ の值も小さくなるため, パワー アシストが実現されることが分かる。なお，(25) 式の第 1 項にかかる $K_{p a}$ はアシストトルクが操作感性の改善効果を 低下させることを防ぐための補正係数である。

(23) 式はクーロン摩擦トルクを無視した場合の理想状態 のリサージュ波形である。しかしながら現実にはクーロン 摩擦トルクが存在するので, (23) 式右辺にクーロン摩擦卜
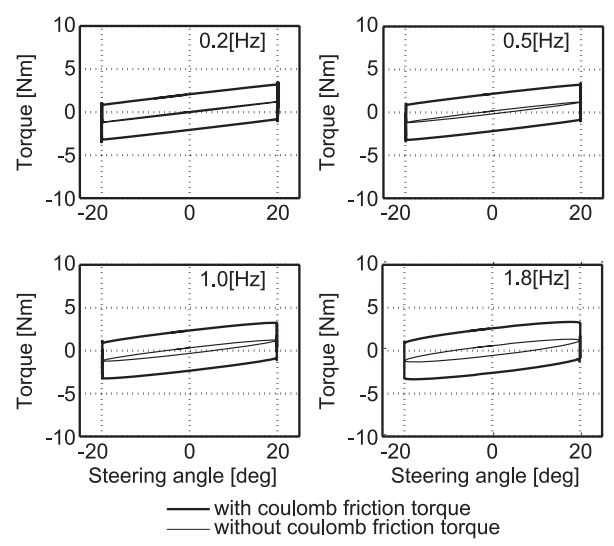

Fig. 4. Ideal Lissajous curves

ルクの項を加えたものを改めて理想状態のリサージュ波形 と呼ぶ。 5 章のテストベンチに対する理想状態のリサージュ 波形を Fig. 4 の太実線にて示す。併せてクーロン摩擦トル クを無視した場合のリサージュ波形を細実線にて示す。こ の細実線で示された楕円の長軸の傾きは, ラックのバネ定 数に対応する。すなわち, 本研究に扔いて操作感性が良い とは，モータの慣性トルクや粘性トルクの影響を受けるこ となく, ラックのバネからの反力をドライバが感じること である。

また，検証実験の際には，センサノイズの影響を除去し， またクーロン摩擦トルクの影響を補償するために, (25) 式 のトルクセンサの目標値 $T_{s n}^{r e f}(s)$ の代わりに次式を用いる。

$$
\begin{aligned}
T_{s n}^{r e f}(s)= & \left\{K_{p a} G_{s}^{\text {cancel }}(s)+G_{c}^{\text {ideal }}(s)\right\} F_{1}(s) \theta_{s}(s) \\
& +F_{2}(s) F_{2 c} \operatorname{sign}\left(\dot{\theta}_{s}\right)-K_{p a} T_{s n}(s)
\end{aligned}
$$

ここで, $F_{1}(s)$ はセンサノイズを取り除くローパスフィル 夕, $F_{2 c}$ はステアリングトルク $T_{s}$ の大きさを調整するため のゲイン, $F_{2}(s)$ はドライバの操舵方向反転時のリサージュ 波形の急激な変化を減らすためのローパスフィルタである。

トルクセンサの目標値に追従するサーボ系として PID コ ントローラを用いると, その制御入力 $v_{2}$ は,

$$
\begin{aligned}
v_{2}= & K_{P}^{a}\left(T_{s n}^{r e f}-T_{s n}\right)+K_{I}^{a} \int_{0}^{t}\left(T_{s n}^{r e f}-T_{s n}\right) d t \\
& +K_{D}^{a} \frac{d}{d t}\left(T_{s n}^{r e f}-T_{s n}\right) \ldots \ldots \ldots \ldots \ldots \ldots \ldots \ldots
\end{aligned}
$$

として表される。

\section{5. テストベンチによる検証}

前章で設計した非干渉制御に基づく角度制御系とトルク 制御系の検証を，テストベンチを用いて行う。

Table 1 の物理パラメータは, 同定実験を行うことで決 定した。また，(24) 式におけるステアリング角度 $\theta_{s}(t)$ か らトルクセンサの目標值 $T_{s n}^{r e f}(t)$ までの伝達特性を Fig. 5 に示す。これより, 操舵周波数带域 $(2[\mathrm{~Hz}]$ 以下) では, 位 相進み特性を示していることが分かる。 


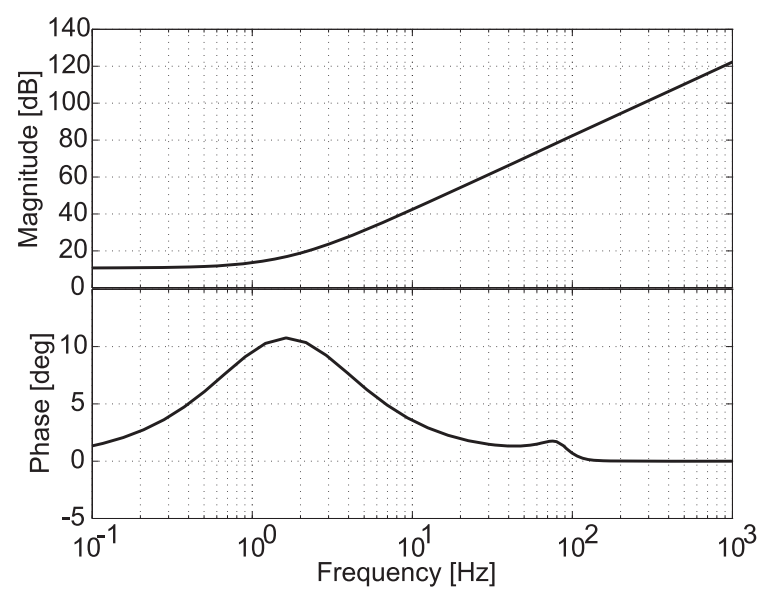

Fig. 5. Frequency characteristic of $\left\{G_{c}^{\text {cancel }}(s)+\right.$ $\left.G_{c}^{\text {ideal }}(s)\right\}$
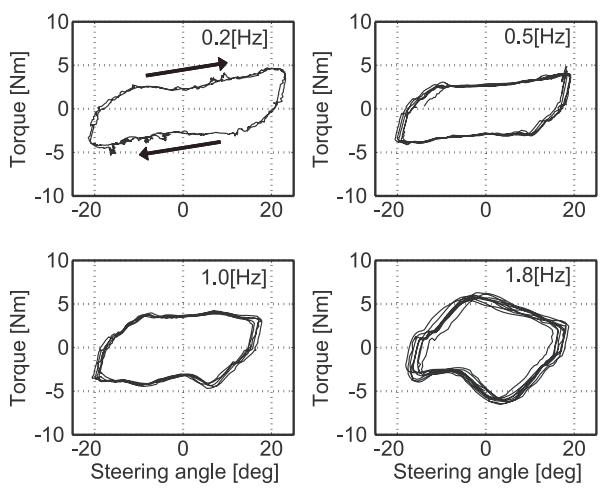

Fig. 6. Lissajous curves without electrification for motor

まず，モータの慣性と粘性が操作感性に与える影響を調べ るために，モー夕を通電しない時のリサージュ波形を Fig. 6 に示す。図中の矢印は，リサージュ波形の回転方向を示す。 これ以降の全てのリサージュ波形の回転方向も同じである ことに注意されたい。Fig. 6 より，操舵周波数が高くなる にしたがい，Fig.4の理想リサージュ波形とは大きく異な ることがわかる。これはモータの慣性トルクの影響に起因 するものである。このとき，ドライバはステアリングを切 り返す際に大きな力が必要であるといった違和感を感じる。 すなわち，これが操作感性の悪い状態である。

次に,アシストトルクが働かない領域における提案手法 の検証を行う。ギア比が $z=1.0, \quad z=0.5, z=2.0$ のリ サージュ波形をそれぞれ Fig. 7, Fig. 8, Fig. 9 に示す。ギ ア比の大きさにかかわらず, Fig. 4 の理想リサージュ波形に 近いことから操作感性が良いことが分かる。ただし，Fig.7 と Fig. 9 の操舵周波数 $1.8[\mathrm{~Hz}]$ のリサージュ波形は，理想 リサージュ波形と比べて傾斜度合いが異なるが，Fig. 6 の補 償しない場合のリサージュ波形と比べて改善効果は大きく， 実用上は操作感性の大幅な改善とみなすことができる。ま た，ギア比制御の性能評価のために，ステアリングを一定 速度で $45[\mathrm{deg}]$ まで操舵し，その状態で保舵する場合の時 間応答を Fig. 10 に示す。これより, 出力軸角度 $\theta_{O}$ が, ス
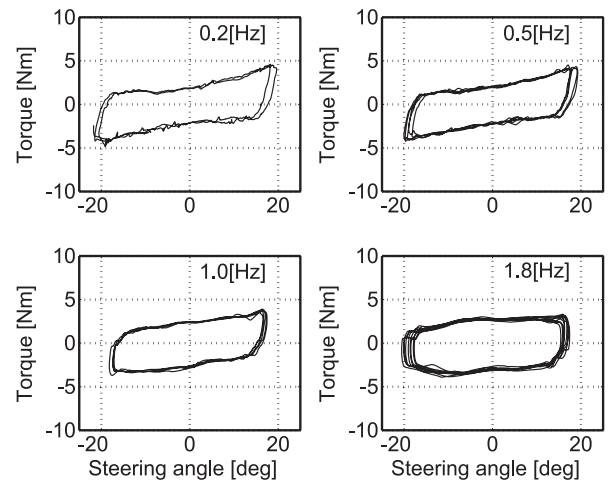

Fig. 7. Lissajous curves with proposed controller without power assist (Gear ratio $z=1$ )
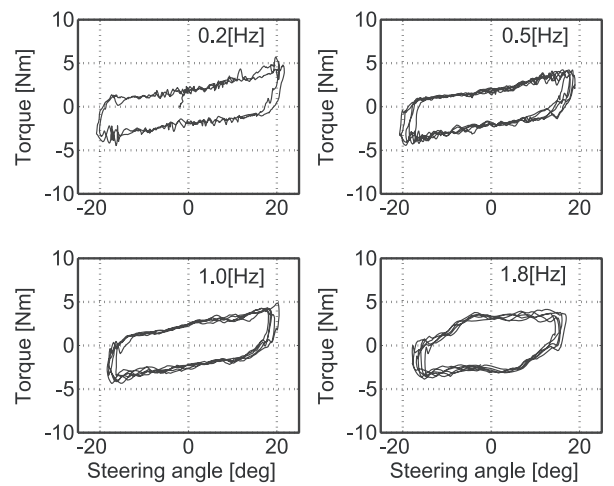

Fig. 8. Lissajous curves with proposed controller without power assist (Gear ratio $z=2$ )
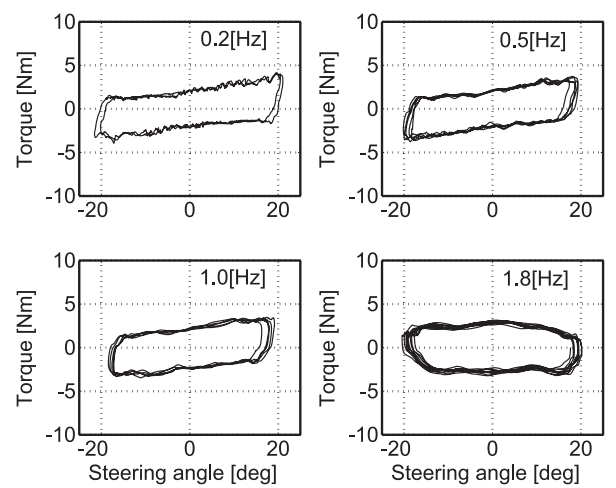

Fig. 9. Lissajous curves with proposed controller without power assist (Gear ratio $z=0.5$ )

テアリングの操舵角 $\theta_{s}$ のギア比 $z$ 倍の角度に追従してい ることから，ギア比制御が達成していることが分かる。

一方，アシストトルクが働く領域における提案手法の検 証を行う。パワーアシストを行った場合のギア比 $z=1$ の リサージュ波形を Fig. 11 に示す。Fig. 7 と Fig. 11 を比較 すると，パワーアシストを行うことでステアリングトルク $T_{s}$ が小さくなることが分かる。操舵周波数 $0.2[\mathrm{~Hz}]$ の場合 で比較すると, 最大值が $4.6[\mathrm{~N} \cdot \mathrm{m}]$ から $2.8[\mathrm{~N} \cdot \mathrm{m}]$ と減少し ている。このことからパワーアシストが実現されているこ とが確認できる。また，すべての操舵周波数において Fig. 4 の理想リサージュ波形に近いことから, 操作感性も改善し ていることが確認できる。なお，ギア比が $z=0.5$ と $z=2$ 


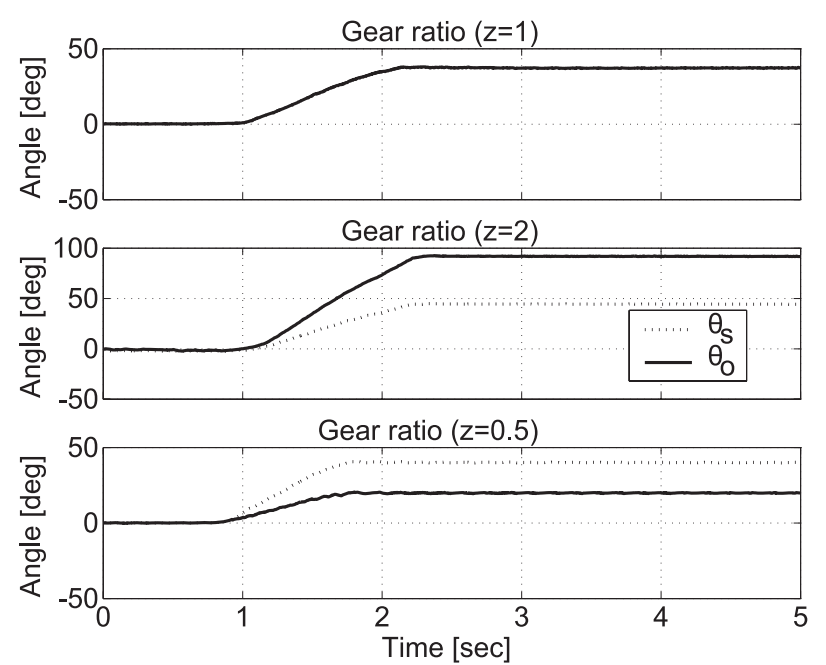

Fig. 10. Responses of steering and output angles
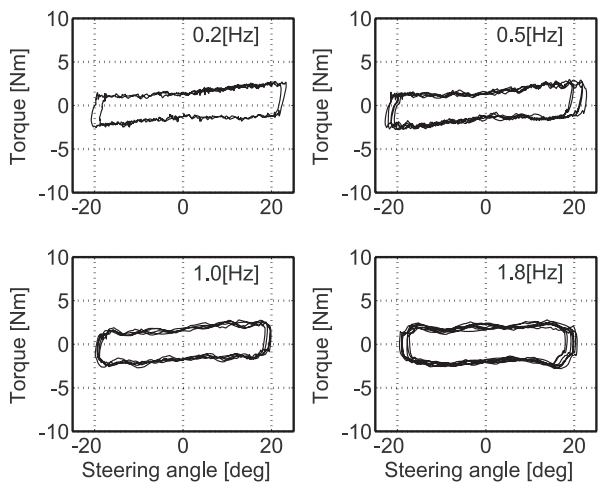

Fig. 11. Lissajous curves with proposed controller with power assist (Gear ratio $z=1$ )
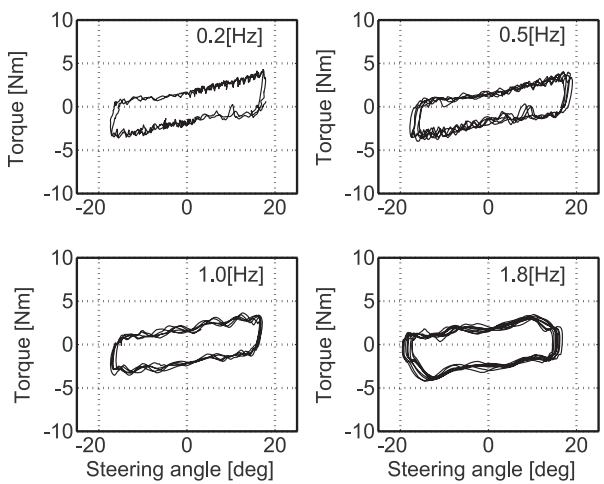

Fig. 12. Lissajous curves without decoupling controller(Gear ratio $z=0.5$ )

の場合も同様の結果を得た。

最後に，非干渉制御を用いないで，角度制御系とトルク 制御系を設計した場合の結果を Fig. 12 に示す。Fig. 4 の理 想リサージュ波形に近いものの, 約 $10[\mathrm{~Hz}]$ の振動がリサー ジュ波形に重畳していることが分かる。これは，トルク制 御系への入力が角度制御系に影響を及ぼし，角度追従が正 しく行えないといった相互干渉の問題が生じているためで ある。これによってステアリング操舵時の振動といった違 和感を感じることを確認した。

\section{6. まとめ}

コラム式の可変ギア伝達機構付電動パワーステアリング の操作感性向上を目的とした非干渉制御に基づく制御系を 提案した。非干渉化された角度制御系とトルク制御系にお いて，前者においてはギア比制御を，後者においては操作 感性の良い，パワーアシスト制御を実現するコントローラ 設計法を提案した。テストベンチを用いた検証実験から，ギ ア比制御の実現と同時に，リサージュ波形に基づく評価か ら操作感性が良いこと, さらにはパワーアシスト制御の実 現を確認した。操作感性については,リサージュ波形の理 想状態のモデルを導出し, それをトルクセンサの目標值と することで，操舵方向反転時のステアリングトルクの増大 や振動による違和感の解消が可能となり, 操作感性が改善 されたことを確認した。

(平成 21 年 4 月 13 日受付, 平成 21 年 8 月 10 日再受付)

\section{文献}

（1）小川計介：「電動化進むステアリング」, 日経 Automotive Technology, 2007-4 号, pp.80-85 (2007)

(2) M. Kurishige, H. Kumamoto, and O. Nishihara: "A New Control Strategy to Reduce Steering Torque for Vehicles Equipped with Electric Power Steering (Steering Angular Velocity Controller Using the Observer for Specified Frequency)", Transactions of the Japan Society of Mechanical Engineers. C, Vol.68, No.675, pp.3238-3245 (2002) (in Japanese)

栗重正彦・熊本博光・西原 修:「電動パワーステアリングの操舵 トルク低隇制御方式：オブザーバを用いた発振周波数に対する ステアリング角速度制御」, 日本機械学論 C 編, Vol.68, No.675, pp.3238-3245 (2002)

（3）杉谷伸夫・藤原幸広・内田健康・藤田政之：「ロードインフォーメー ションを考慮した電動パワーステアリング制御」, 自技会学術講演 会前刷集 964, pp.129-132 (1996)

（4）本山廉夫：「電動パワーステアリング制御「EPS+」の開発」, 三菱 自動車テクニカルレビュー、No.20,pp.97-98 (2008)

（5）藤原幸広・足立修一:「電動パワーステアリング制御手法に関する一 考察—ドライバ操舵トルク推定による制御系の構成一」. Dynamical System Theory シンポジウム資料, pp.257-260 (2000)

（6）井尻和一郎·筒井高志:「電動パワーステアリングの技術動向」, KOYO Engineering Journal, No.162, pp.28-32 (2002)

(7) K. Yubai, Y. Uga, T. Suzuki, S. Okuma, and T. Daidou: "Design Method of Electric Power Steering Control System Using Scheduled $H_{\infty}$ Control", Trans. IEEJ, Vol.119-C, No.1, pp.83-90 (1999-1) (in Japanese)

弓場井一裕・宇賀雄次・鈴木達也・大熊繁・大道俊彦：「スケジュー ルド $H_{\infty}$ 制御を用いた電動パワーステアリング駆動系の設計手法」, 電学論 C, 119, 1, pp.83-90 (1999-1)

(8) S. Takehara and T. Yoshioka: "Improvement of Steering and Vehicle Characteristics due to Electric Power Assist Steering with Disturbance Observer", Transactions of the Japan Society of Mechanical Engineers. C, Vol.70, No.698, pp.2913-2916 (2004) (in Japanese)

竹原 伸・吉岡 透:「外乱オブザーバを用いた電動パワーステアリ ングによる操舵/車両応答特性の向上」, 日本機械学論 C 編, Vol.70, No.698, pp.2913-2916 (2004)

(9) M. Yokoyama, T. Kawasaki, and M. Tsuchiya: "Sliding Mode Control Electric Power Assist Systems", Transactions of the Japan Society of Mechanical Engineers. C, Vol.72, No.721, pp.2838-2844 (2006) (in Japanese)

横山 誠・川崎貴史・土屋雅彦：「電動パワーアシスト装置のス ライディングモード制御」, 日本機械学論 C 編, Vol.72, No.721, pp.2838-2844 (2006)

（10）小川計介：「レクサスの挑戦」，日経 Automotive Technology, 2005/10 号, p.146 (2005) 
(11) Y. Mukai, H. Ukai, M. Iwasaki, N. Matsui, et al.: "Improvement of Maneuvering Feeling of Human-Mechanical Cooperative System and Its Application to Electric Power Steering System", Proc. of Int. Conf. on Control, Automation, and Systems (ICCAS2003) (2003)

(12) Y. Morita, K. Torii, N. Tsuchida, H. Ukai, M. Iwasaki, N. Matsui, et al.: "Decoupling Control of Electric Power Steering System with Variable Gear Transmission System", Procs. of the 32nd Annual Conf. of the IEEE Industrial Electronics Society (IECON'06), pp.5364-5269 (2006)

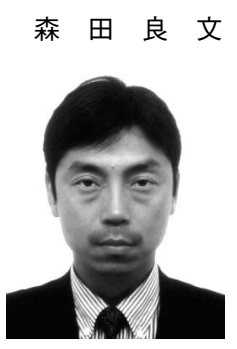

（上級会員） 1964 年生。1989 年 3 月名古屋工業 大学大学院工学研究科博士前期課程修了。同年 4 月 (株) 日本電装 (現在, (株) デンソー) に入 社。1991 年 3 年 10 月岐皁工業高等専門学校電 子制御工学科助手。 2000 年 4 月名古屋工業大学 電気情報工学科講師, 現在, 同大学大学院工学研 究科教授。工学博士。ロボットの運動制御, 人間 機械協調系の支援制御, リハビリロボットの研究 に従事。計測自動制御学会, 日本機械学会, IEEE 会員。

横 井 彰 敏 (学生員) 1984 年生。 2007 年 3 月岐阜大学工

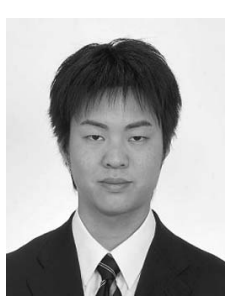
学部電気電子工学科卒業。2009 年 3 月名古屋工 業大学大学院工学研究科情報工学専攻修了。在学 中，電動パワーステアリングの制御に関する研究 に従事。

岩 崎 誠（上級会員） 1964 年生。1991 年 3 月名古屋工業

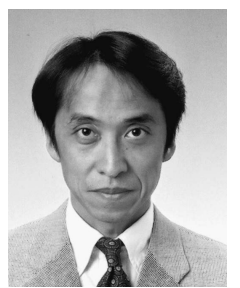
大学大学院工学研究科博士後期課程修了。同年 4 月, 同大学電気情報工学科助手, 現在, 同大学大 学院工学研究科教授。工学博士。運動制御の研究 に従事。精密工学会, IEEE 会員。

鵜 飼 裕 之（上級会員） 1954 年生。1979 年 3 月名古屋工業

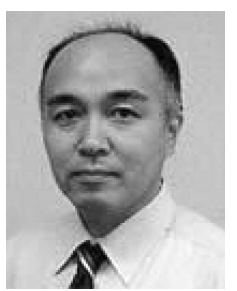
大学大学院計測工学専攻修了。1980 年同大学電 気工学科助手, 現在, 同大学大学院工学研究科教 授。工学博士。電力系統の監視制御システムおよ びロボット制御に関する研究に従事。計測自動制 御学会, 日本原子力学会, 高速信号処理応用技術 学会, IEEE 会員。
松 井 信 行 （上級会員） 1943 年生。1968 年 3 月名古屋工業

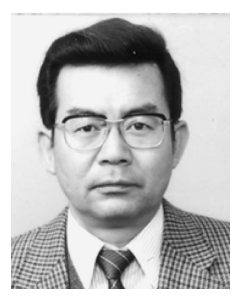
大学大学院修士課程修了。同年 4 月, 同大学助手, 講師，助教授を経て，1985 年 4 月，電気情報工 学科教授，2000 年 4 月より 2002 年 10 月まで同 大学副学長, 同年 11 月に教授に復職後, 2004 年 1 月同大学学長。工学博士。パワーエレクトロニ クスおよびモーションコントロールの研究と教育 に従事。2001 年電気学会部門活動功労賞，2002 年電気学会学術振興賞 (論文賞), 同優秀技術活動賞, 同产業応用特別 賞 (貢献賞)，小平記念賞，2004 年 Best Transactions Paper Award from IEEE Industrial Electronics Society, 2009 年電気学会電気学 術振興賞（進歩賞）受賞。計測自動制御学会会員，IEEE Fellow。

伊 藤 徳 久（非会員） 1960 年生。1984 年 4 月（株）日本電

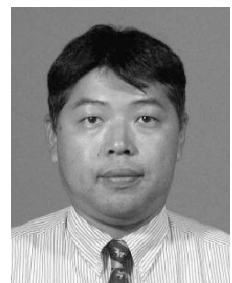
装（現在，（株）デンソー）に入社。現在，電気 制御機器部電気制御技術企画室室長。

瓜生 信 彦（非会員） 1966 年生。1988 年 4 月（株）日本電

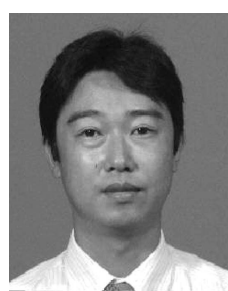
装（現在，（株）デンソー）に入社。現在，電気 制御機器部電気制御技術企画室主幹。

向 井 靖 彦 (非会員) 1978 年生。2002 年 3 月名古屋工業

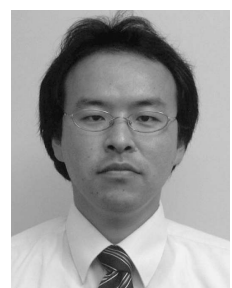
大学電気情報工学科卒業。 2004 年 3 月同大学大 学院工学研究科システムマネジメント工学専攻修 了。2004 年 4 月（株）日本電装（現在，(株）デ ンソー) に入社。現在，電気制御機器部 電気制御 技術企画室。 